\title{
Decompensated heart failure
}

\author{
Insuficiência cardíaca descompensada
}

\author{
Sandrigo Mangini ${ }^{1}$, Philippe Vieira Pires ${ }^{2}$, Fabiana Goulart Marcondes Braga ${ }^{3}$, Fernando Bacal ${ }^{1}$
}

\begin{abstract}
Heart failure is a disease with high incidence and prevalence in the population. The costs with hospitalization for decompensated heart failure reach approximately $60 \%$ of the total cost with heart failure treatment, and mortality during hospitalization varies according to the studied population, and could achieve values of $10 \%$. In patients with decompensated heart failure, history and physical examination are of great value for the diagnosis of the syndrome, and also can help the physician to identify the beginning of symptoms, and give information about etiology, causes and prognosis of the disease. The initial objective of decompensated heart failure treatment is the hemodynamic and symptomatic improvement preservation and/or improvement of renal function, prevention of myocardial damage, modulation of the neurohormonal and/or inflammatory activation and control of comorbidities that can cause or contribute to progression of the syndrome. According to the clinical-hemodynamic profile, it is possible to establish a rational for the treatment of decompensated heart failure, individualizing the proceedings to be held, leading to reduction in the period of hospitalization and consequently reducing overall mortality.
\end{abstract}

Keywords: Heart failure/diagnosis; Heart failure/therapy; Prognosis

\section{RESUMO}

A insuficiência cardíaca apresenta elevada incidência e prevalência em todo mundo. Os custos com internação por insuficiência cardíaca descompensada chegam a aproximadamente $60 \%$ do custo total do tratamento da insuficiência cardíaca, e a mortalidade durante a internação varia conforme a população estudada, podendo chegar a 10\%. Em pacientes com insuficiência cardíaca descompensada, os achados de história e exame físico são de grande valor por fornecerem, além do diagnóstico da síndrome, o tempo de início dos sintomas, as informações sobre etiologia, as causas de descompensação e 0 prognóstico. 0 objetivo inicial do tratamento da insuficiência cardíaca descompensada é a melhora hemodinâmica e sintomática. Além disso, outros alvos devem ser buscados, incluindo preservação e/ou melhora da função renal, prevenção de lesão miocárdica, modulação da ativação neuro-hormonal e/ou inflamatória, e manejo de comorbidades que podem causar ou contribuir para progressão da síndrome. Com base nos perfis clínico-hemodinâmicos, é possível estabelecer um racional para 0 tratamento da insuficiência cardíaca descompensada, individualizando o procedimento a ser instituído e objetivando redução de tempo de internação e de mortalidade.

Descritores: Insuficiência cardíaca/diagnóstico; Insuficiência cardíaca/ terapia; Prognóstico

\section{INTRODUCTION}

Decompensated heart failure (DHF) is defined as a clinical syndrome in which a structural or functional change in the heart leads to its inability to eject and/ or accommodate blood within physiological pressure levels, thus causing a functional limitation and requiring immediate therapeutic intervention ${ }^{(1)}$. It has an irrefutable epidemiological importance, and clinical peculiarities that directly influence treatment. The objective of this study is to guide clinicians on the current management of DHF.

\section{EPIDEMIOLOGY}

HF has a high incidence and prevalence worldwide. One to two percent of the population of developed countries are estimated to have $\mathrm{HF}$, and this prevalence increases to $10 \%$ in the population 70 years of age or over. In Europe, 10 million people are estimated to have HF with associated ventricular dysfunction, and other 10 million, to have HF with preserved ejection fraction

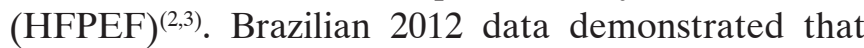

\footnotetext{
${ }^{1}$ Hospital Israelita Albert Einstein, São Paulo, SP, Brazil; Hospital das Clínicas, Faculdade de Medicina, Universidade de São Paulo, São Paulo, SP, Brazil.

${ }^{2}$ Hospital Israelita Albert Einstein, São Paulo, SP, Brazil.

${ }^{3}$ Hospital das Clínicas, Faculdade de Medicina, Universidade de São Paulo, São Paulo, SP, Brazil.

Corresponding author: Sandrigo Mangini - Avenida Albert Einstein, 627, building A1, 4th floor - Morumbi -Zip code: 05652-900 - São Paulo, SP, Brazil - Phone: (55 11) 2151-5420 - E-mail: sandrigo@einstein.br

Received on: Feb 15, 2013 - Accepted on: Aug 13, 2013
} 
$21.5 \%$ of $1,137,572$ hospitalizations for diseases of the circulatory system were for $\mathrm{HF}$, with a $9.5 \%$ in-hospital mortality, and $70 \%$ of the cases in the age range above 60 years $^{(4)}$.

Costs with hospitalizations for decompensation reach approximately $60 \%$ of the total expenditures with the treatment of $\mathrm{HF}^{(5)}$. Mortality rate among patients discharged within 90 days is of approximately $10 \%$, with roughly $25 \%$ of readmissions in the period ${ }^{(5)}$.

Ischemic cardiomyopathy is considered the most common cause of $\mathrm{HF}^{(6)}$. However, in Brazil, hypertensive, chagasic, and valvular cardiomyopathies play an important role, including in relation to hospitalizations for decompensation $^{(7,8)}$.

\section{CLASSIFICATION OF DECOMPENSATED HEART FAILURE}

DHF may present in the acute form or as an acute exacerbation of chronic HF, and may be classified as follows ${ }^{(8)}$.

\section{“New" acute HF (not previously diagnosed)}

Clinical HF syndrome which occurs in patients with no previous signs and symptoms of HF, triggered by clinical situations such as acute myocardial infarction, hypertensive crisis, and rupture of the mitral chordae tendineae. In this context, pulmonary congestion is usually present without systemic congestion, and blood volume is generally normal. The use of high doses of diuretics is not indicated, but rather treatment of the primary cause of decompensation (vasodilator in hypertensive crisis, artery opening in acute coronary syndrome - ACS, and correction of mitral regurgitation in rupture of the chordae tendineae).

\section{Decompensated chronic HF (acute exacerbation of chronic HF)}

Clinical situation in which there is acute or gradual exacerbation of signs and symptoms of HF at rest in patients previously diagnosed with $\mathrm{HF}$, that requires additional and immediate therapy. This is the most frequent clinical presentation of $\mathrm{DHF}^{(8)}$, and its most common cause is low treatment adherence (water and sodium restriction and inadequate use of medications). Other important causes include: infection, pulmonary embolism, use of medications such as antiinflammatory drugs, and tachy- or bradiarrhythmias. It is usually related to pulmonary and/or systemic congestion, with evident hypervolemia. In addition to seeking the cause of decompensation, volume management with diuretics is crucial.

\section{CLINICAL PRESENTATION}

In patients with DHF, findings from history taking and physical examination are important not only for providing the diagnosis of the syndrome, but also the time of onset of symptoms, information on the etiology, causes of decompensation (Chart 1) and prognosis.

Chart 1. Triggering factors of decompensation in heart failure

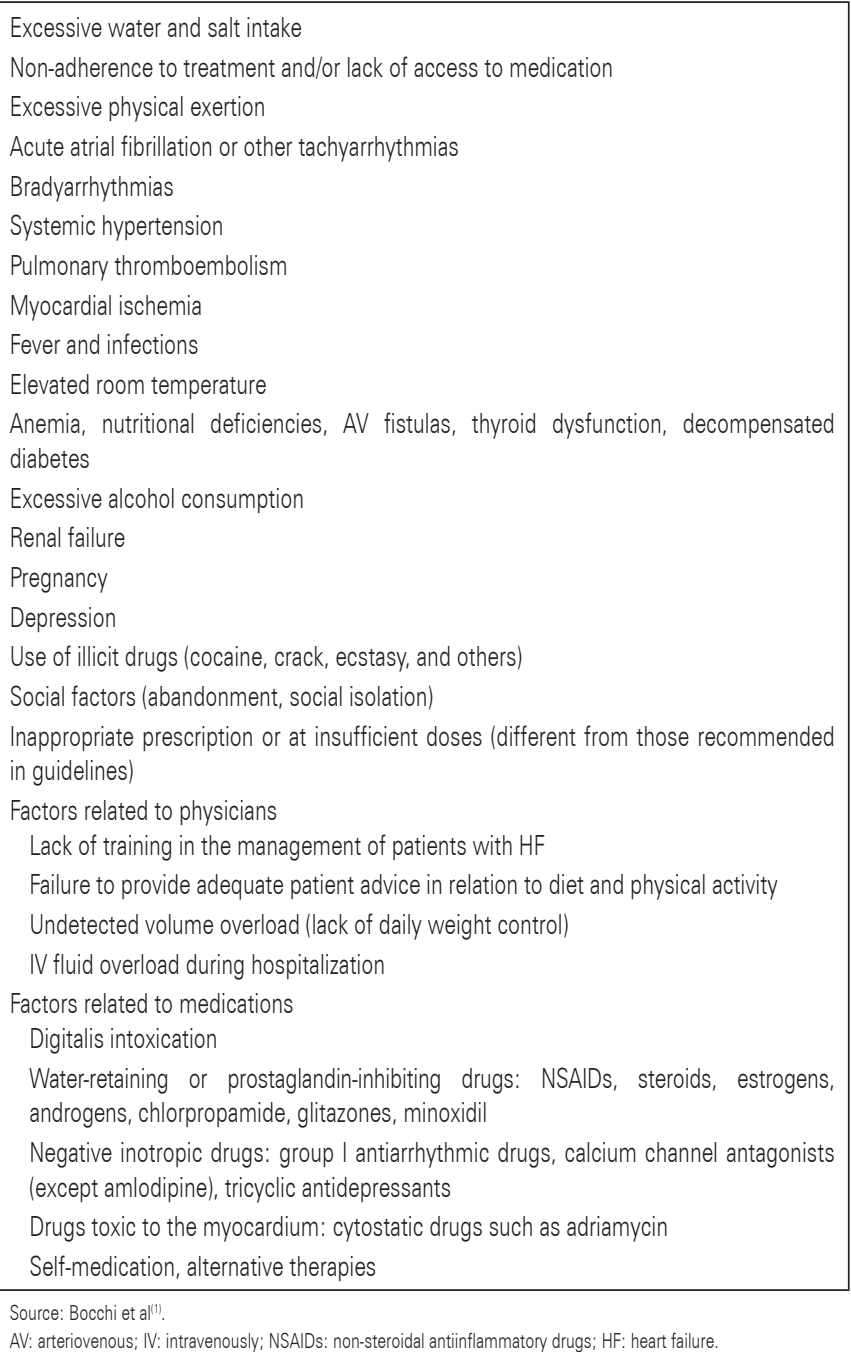

The most common and characteristic symptom of DHF is dyspnea. However, this finding has low specificity, and may be found in other clinical conditions. This is also true for the presence of nocturnal cough, leg edema, pulmonary wheezes or rales. On the other hand, orthopnea, paroxysmal nocturnal dyspnea, and presence of the third heart sound, although not pathognomonic, are more specific signs and symptoms of $\mathrm{HF}^{(9)}$. Personal health and family history, as well as the review of systems, may add data to infer the etiology and presence of comorbidities. 
Identifying the cause is important, since it can help to choose specific therapies (myocardial revascularization in ischemic cardiomyopathy), to infer the prognosis (greater severity of chagasic and ischemic

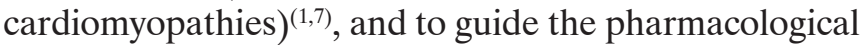
treatment of decompensation.

Based on the findings of bedside physical examination, it is possible to define the clinical-hemodynamic profile with the purpose of guiding treatment of DHF, as well as stratifying its risk using congestion and perfusion parameters. The presence of congestion can be inferred in $70 \%$ to $80 \%$ of DHF cases, by means of signs of tachypnea, pulmonary crackles, third heart sound, increased jugular venous pressure, leg edema, tender hepatomegaly, hepatojugular reflux, pleural effusion and ascites. The presence of poor perfusion is related to the findings of tachypnea, hypotension, pulsus alternans, prolonged capillary filling time, cyanosis, and abnormal level of consciousness.

According to the algorithm developed by Stevenson ${ }^{(10)}$, patients presenting with congestion are classified as "wet", whereas patients without congestion are called "dry". Patients with inadequate perfusion are classified as "cold", whereas those with good perfusion are classified as "warm". Thus, four clinical-hemodynamic profiles are defined (Figure 1): profile A ("dry-warm" or compensated); profile B ("wet-warm", which is the most common type); profile C ("wet-cold", with the worst prognosis); and profile L ("dry-cold", which is not frequent).

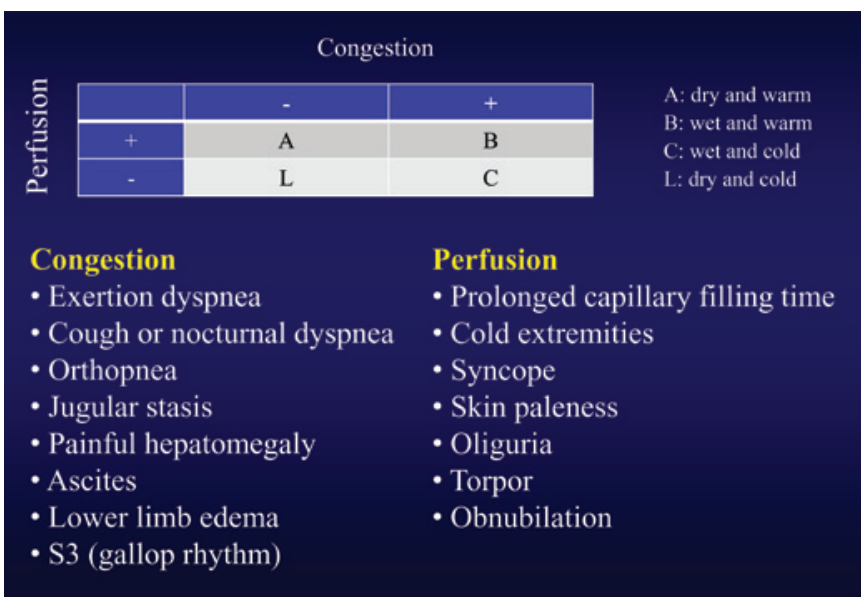

Figure 1. Clinical assessment of decompensated heart failure

\section{DIAGNOSTIC STUDIES IN DECOMPENSATED HEART FAILURE}

Although the diagnosis of DHF is made based on data from history and physical examination, diagnostic studies are important because, in addition to confirming the diagnosis, they also provide data on the degree of cardiac remodeling, the presence of systolic and/or diastolic dysfunction, etiology, cause of decompensation, presence of comorbidities, and risk stratification (Figure 2). Among the diagnostic studies available, the following are specially helpful.

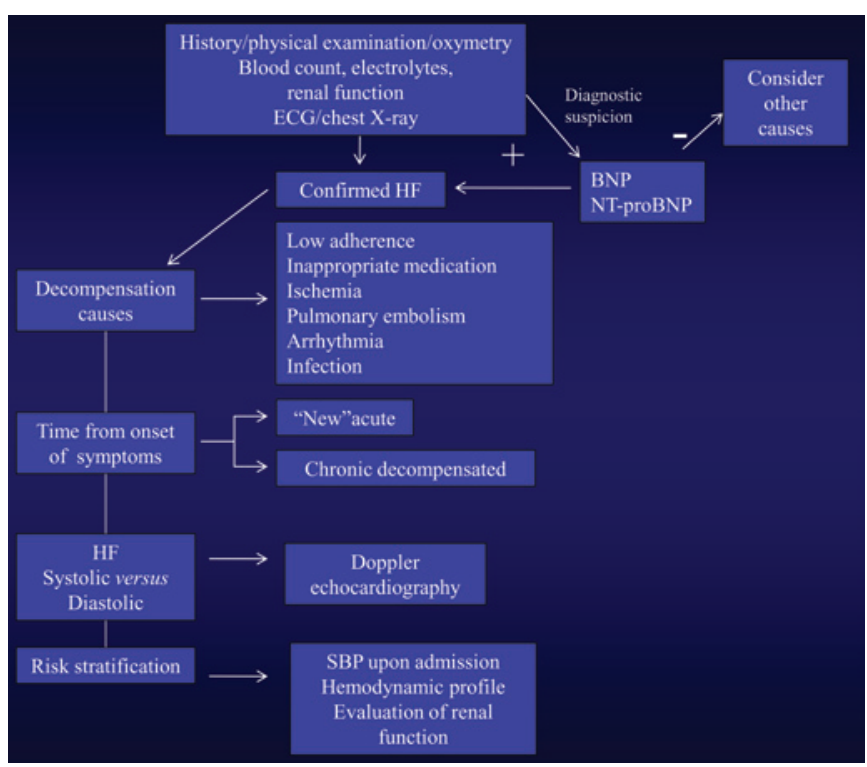

ECG: electrocardiogram; HF: heart failure; BNP: brain natriuretic peptide; SBP: systolic blood pressure

Figure 2. Diagnostic assessment of decompensated heart failure

\section{Electrocardiography}

Fundamental in the management of ACS. Some findings may suggest specific etiologies: the presence of $\mathrm{Q}$ waves, absence of $\mathrm{R}$ wave progression in precordial leads and repolarization abnormalities, especially of the ST-segment, suggest an ischemic component; the association of right bundle branch block with left anterior superior division block suggests Chagas disease; low voltage in the frontal plane suggests storage disease and pericardial effusion. The presence of left bundle branch block may correspond to acute myocardial infarction or pronounced myocardial remodeling, thus characterizing a poor prognosis. Bradyarrhythmias and tachyarrhythmias may be the cause of DHF, and have therapeutic and prognostic implications.

\section{Laboratory tests}

Blood count, BUN, creatinine, blood glucose, electrolytes, and urinalysis are simple methods that help define comorbidities, the cause of decompensation, prognosis and treatment. When ACS is suspected, myocardial 
necrosis markers are important for the diagnosis; also, increased levels in the absence of obstructive coronary disease have a prognostic value. Arterial blood gases, central venous blood gases, lactate, and tests to check liver integrity and function should be performed in more severely ill patients. Thyroid profile and serologic test for Chagas disease may be considered.

\section{Biomarkers}

Biomarkers are useful in the diagnosis and prognosis of DHF. Among the several biomarkers that have been studied, natriuretic peptides, BNP and NT-ProBNP are the most widely used and well established in the clinical practice. They are produced mainly in the ventricles, in response to increased ventricular wall tension. Determination of their levels is indicated for the differential diagnosis of dyspnea in the emergency room $^{(11,12)}$. Increased levels are found in systolic dysfunction and in HFPEF (greater levels in systolic dysfunction). They have prognostic value and have been considered markers of response to the treatment of DHF, despite controversial findings ${ }^{(13,14)}$. Recently, a Brazilian study demonstrated a diagnostic and prognostic impact of exhaled acetone in $\mathrm{DHF}^{(15)}$.

\section{Echocardiography}

This is the main noninvasive method for the diagnosis of HF. In patients with DHF, it is indicated to help find the etiology and establish the prognosis, in addition to give information on the type of dysfunction (systolic and/or diastolic), chambers affected, heart valve lesions, segmental contractility abnormalities and pericardium. In DHF, it may show the progression of dysfunction and the cause of decompensation (pericardial effusion, pulmonary embolism, and acute ischemia). It also may be used for the definition of the hemodynamic profile and to guide therapy (hemodynamic echo) ${ }^{(16)}$.

\section{Pulmonary artery catheter}

It permits the direct analysis of intracardiac and intravascular pressures, as well as of microhemodynamics parameters. It is indicated to help treat patients with DHF, especially in the presence of shock and for the assessment of the pulmonary vascular resistance, to indicate cardiac transplantation. The ESCAPE study did not show benefit of the use of a pulmonary artery catheter in the treatment of DHF without cardiogenic shock ${ }^{(17)}$.

\section{RISK STRATIFICATION IN DECOMPENSATED HEART FAILURE}

As shown in chart 2, there is a series of poor-prognosis factors related to $\mathrm{DHF}^{(1)}$. Among those mentioned, we should point out systolic blood pressure (SBP) and renal function (ADHERE registry) ${ }^{(18)}$. Patients with DHF presenting BUN $>90 \mathrm{mg} / \mathrm{dL}, \mathrm{SBP}<115 \mathrm{mmHg}$ and creatinine $>2.75 \mathrm{mg} / \mathrm{dL}$ on admission have a $21.9 \%$ risk of in-hospital mortality; on the other hand, patients not presenting these characteristics have a low mortality risk $(2.14 \%)$. In DHF, the cardiorenal syndrome is related to different mechanisms, in special, renal hypoperfusion due to myocardial dysfunction or hypovolemia and systemic congestion with renal venous hypertension $^{(19)}$. An increase by $0.3 \mathrm{mg} / \mathrm{dL}$ in creatinine levels on admission is related to higher mortality ${ }^{(20)}$.

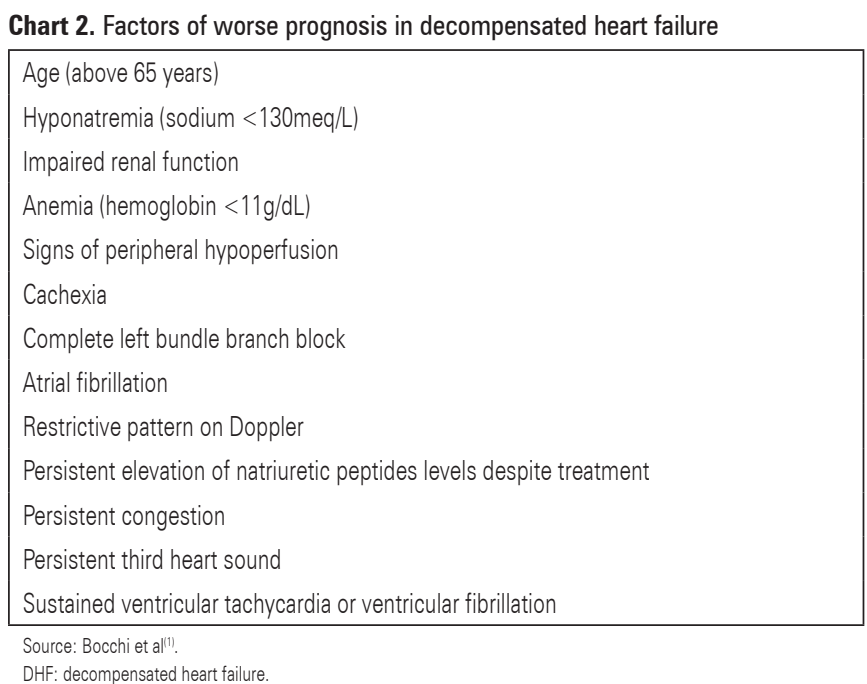

\section{TREATMENT OF DECOMPENSATED HEART FAILURE}

The initial objective of the treatment of DHF is to achieve hemodynamic and symptomatic improvement. In addition, other targets should be sought, including the preservation and/or improvement of the renal function, prevention of myocardial damage, modulation of the neurohormonal and/or inflammatory activation, and management of comorbidities that could cause or contribute to the progression of the syndrome ${ }^{(21)}$.

Based on the hemodynamic profiles proposed by Stevenson, on the assessment of volemia, on the definition of the time of onset of symptoms, on the cause of decompensation, and on the SBP, it is possible to establish a rationale for the treatment of DHF (Figure 3).

Most of the patients with decompensation show a predominance of pulmonary and/or systemic congestion and adequate peripheral perfusion ("wet-warm" pattern - profile B), and their treatment include vasodilators 


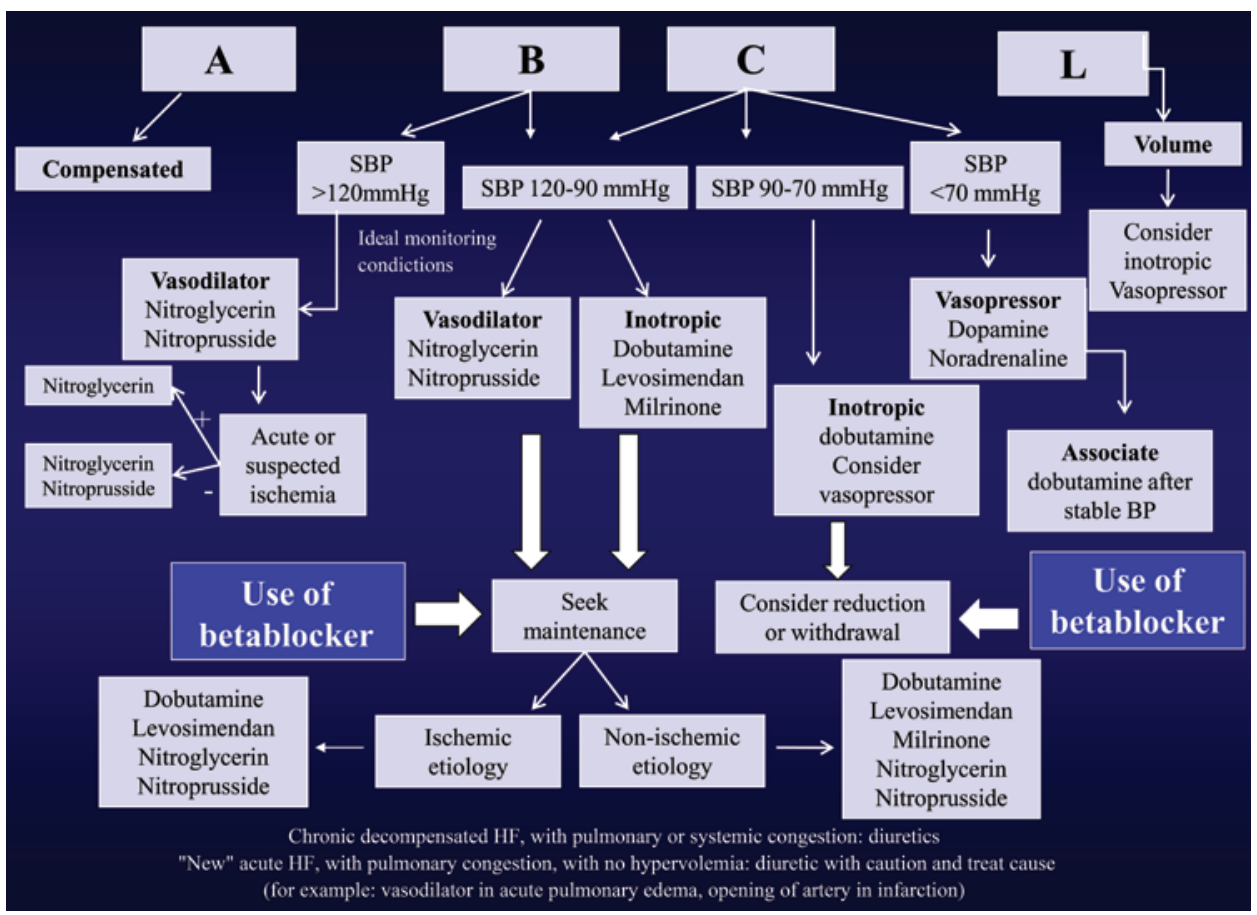

A: dry-warm; B: wet-warm; C: wet-cold; L: dry-cold; SBP: systolic blood pressure; BP: blood pressure; HF: heart failure; APE: acute pulmonary edema.

Figure 3. Treatment algorithm of decompensated heart failure

and diuretics. If worsening of the renal function occurs, inotropic drugs should be considered (especially when the SBP is between 90 and $120 \mathrm{mmHg}$ ). In situations of congestion and poor peripheral perfusion ("wet-cold" pattern - profile C), inotropic drugs and diuretics are indicated; if BP is being intensively monitored, it is also possible to use intravenous vasodilators. The finding of poor perfusion without pulmonary congestion is rare ("dry-cold" pattern - profile L) and usually responds to volume (inotropic drugs may be necessary).

Criteria for hospitalization are shown in Chart $3^{(1)}$.

Chart 3. Criteria for hospitalization

\begin{tabular}{|c|c|}
\hline \multirow{7}{*}{$\begin{array}{l}\text { Criteria for } \\
\text { immediate } \\
\text { hospitalization }\end{array}$} & Pulmonary edema or respiratory distress in the sitting position \\
\hline & Oxygen saturation $<90 \%$ \\
\hline & Heart rate $>120 \mathrm{bpm}$ in the absence of chronic atrial fibrillation \\
\hline & Systolic blood pressure $<75 \mathrm{mmHg}$ \\
\hline & Mental disorder attributable to hypoperfusion \\
\hline & Decompensation in the presence of acute coronary syndromes \\
\hline & "New" acute HF \\
\hline \multirow{3}{*}{$\begin{array}{l}\text { Criteria } \\
\text { for urgent } \\
\text { hospitalization }\end{array}$} & Severe liver distension, massive ascites or anasarca \\
\hline & $\begin{array}{l}\text { Decompensation in the presence of acutely decompensated non- } \\
\text { cardiac conditions, such as pulmonary disease or renal dysfunction }\end{array}$ \\
\hline & Rapid and progressive onset of symptoms of HF \\
\hline \multirow{4}{*}{$\begin{array}{l}\text { Consider } \\
\text { hospitalization }\end{array}$} & Rapid drop in serum sodium (<130meq/L) \\
\hline & Rapid elevation of creatinine (>2.5mg/dL) \\
\hline & Symptoms persist at rest, despite optimized oral treatment \\
\hline & Comorbidity with expected worsening of HF \\
\hline
\end{tabular}

\section{CLINICAL TREATMENT}

\section{Non-pharmacological measures}

Despite limited evidence, water and sodium restriction should be used in a customized fashion, and the daily weight should be used as a parameter of response to treatment.

\section{Monitoring and ventilatory support}

Patients presenting with any sign of instability should be monitored by continuous electrocardiogram (ECG), noninvasive blood pressure and oximetry. Regardless of the form of presentation, hypoxia should be corrected in an attempt to ensure adequate oxygenation and reduce the respiratory work. Noninvasive ventilation (CPAP or BiPAP) resulted in a reduction of intubations and mortality, especially in acute pulmonary edema ${ }^{(22)}$.

\section{Vasodilators}

Vasodilators act on the preload and afterload, requiring less myocardial consumptions than inotropic drugs. Retrospective studies have demonstrated lower mortality in DHF with the use of vasodilators ${ }^{(23,24)}$. They are indicated in situations of pulmonary and systemic congestion (profiles B and C) and in individuals with poor peripheral perfusion and $\mathrm{SBP}>90 \mathrm{mmHg}$ (profile C). The use of these agents requires intensive SBP monitoring and dose titration. In profile $\mathrm{B}$ patients who 
are asymptomatic at rest and with $\mathrm{SBP}>120 \mathrm{mmHg}$, it is possible to use oral vasodilators and diuretics. Intravenous vasodilators should be used in patients with dyspnea at rest, and in acute pulmonary edema. These drugs should be avoided in patients with hypotension $(\mathrm{SBP}<90 \mathrm{mmHg})$, hypovolemia and recent use of phosphodiesterase-5 inhibitors (sildenafil, vardenafil and tadalafil).

\section{Nitroglycerin ${ }^{(25)}$}

Nitroglycerin is a short-acting intravenous vasodilator. Small doses (30 to $40 \mu \mathrm{g} / \mathrm{min}$ ) induce venodilatation, whereas higher doses $(250 \mu \mathrm{g} / \mathrm{min})$ cause arteriolar dilatation. Its benefits derive from venous dilatation, with relief in pulmonary congestion and increase in coronary flow, thus justifying its use in DHF associated with ACS. Headache and nausea are common side effects.

\section{Sodium nitroprusside $\mathrm{e}^{(25)}$}

A potent arterial and venous vasodilator, sodium nitroprusside reduces the preload and afterload, thus improving the biventricular systolic performance. The usual dose is 0.5 to $10 \mu \mathrm{g} / \mathrm{kg} / \mathrm{min}$. It should be avoided in ACS because of the risk of decreasing the coronary perfusion pressure and "coronary steal". Arterial hypotension is the most common side effect and may lead to hypoperfusion and worsening of the renal function.

Sudden discontinuation may cause a rebound effect. Thus, gradual withdrawal is advised, with the use of oral vasodilators. When high doses are used for a long period, especially in patients with renal and/or hepatic dysfunction, there is a risk of intoxication by thiocyanate and cyanide.

\section{Inotropic agents $^{(26)}$}

In patients with low cardiac output, with or without congestion (profiles L and C), inotropic therapy may be required to improve tissue perfusion ${ }^{(5)}$. Although these drugs have been effectively used to increase perfusion and cardiac output, these hemodynamic parameters are not associated with better outcomes in patients with HF. They are associated with ischemia, and the intermittent use is not recommended. These agents are appropriate for short-term therapy in patients with hemodynamic deterioration, patients with chronic HF, increased levels of nitrogenous waste, and those who did not achieve satisfactory diuresis with diuretics and vasodilators. They are also efficient in the hemodynamic support of patients awaiting cardiac transplantation or revascularization, and may save lives in situations of cardiogenic shock. These drugs are not indicated in patients with HFPEF.

\section{Dobutamine}

Dobutamine is a beta-adrenergic agonist. It stimulates beta-adrenergic receptors 1 and 2, thus promoting elevation of adenyl cyclase and the subsequent increase in the intracellular calcium concentration, resulting in inotropism and chronotropism.

Its most common adverse effects are ischemia and arrhythmias, because of increased oxygen consumption.

Despite data suggesting increased mortality, dobutamine is the most widely used inotropic agent ${ }^{(27)}$. It provides hemodynamic improvement, with a dose-dependent increase in the cardiac output, and usually does not cause hypotension. It should be restricted to patients with DHF in profiles C and L, at a dose of 3 to $20 \mu \mathrm{g} / \mathrm{kg} / \mathrm{min}$. In hypotensive patients $(\mathrm{SBP}<70 \mathrm{mmHg})$, combination with a vasopressor (dopamine or norepinephrine) may be considered.

\section{Milrinone}

Milrinone is a phosphodiesterase-III inhibitor. An inodilator agent for its inotropic and vasodilator properties (both systemic and pulmonary), it increases cardiac contractility and produces arterial and venous dilation by means of the increase in intracellular concentrations of cyclic AMP and calcium. It promotes an increase in cardiac output and reduction in the pulmonary and systemic vascular resistance.

A study has demonstrated increased mortality, especially in the ischemic etiology ${ }^{(28)}$. Because its mechanism of action does not depend on the adrenergic system, milrinone may be an option for patients using betablockers (aiming at maintaining them). Among its side effects, we should point out its arrhythmogenic potential (atrial and/or ventricular). The recommended dose ranges from 0.3 to $0.75 \mu \mathrm{g} / \mathrm{kg} / \mathrm{min}$. Due to the risk of hypotension, the loading dose is not recommended. In patients with renal failure, dose should be adjusted.

\section{Levosimendan}

Levosimendan is a calcium sensitizer. It exerts an inotropic action, increasing troponin $\mathrm{C}$ sensitivity to calcium that is already available in the cytoplasm, without additional calcium overload. It promotes contractile and hemodynamic improvement similar to other inotropic drugs and has a vasodilator action by activating ATPdependent potassium channels ${ }^{(29)}$. Levosimendan is safe and efficient in DHF of different etiologies, especially in patients using betablockers ${ }^{(30,31)}$. Its half-life is long, with active metabolites maintaining their effect for up to 7 days.

The major side effects include hypotension, headache, and arrhythmias (atrial and ventricular). The SURVIVE 
study ${ }^{(32)}$ compared levosimendan with dobutamine in patients eligible for inotropic support, and found no difference in the 180-day mortality. A maintenance dose of $0.1 \mu \mathrm{g} / \mathrm{kg} / \mathrm{min}$, in 24 hours, without a loading dose, has been suggested to reduce the side effects.

\section{Vasopressors}

The most frequently used vasopressors are norepinephine and dopamine, which are indicated in symptomatic hypotension despite correction of volemia. Norepinephrine has a high affinity for alpha-adrenergic receptors and moderate affinity for beta-adrenergic receptors, with consequent and significant vasoconstriction, mild increase of the heart rate, inotropism and increased myocardial oxygen consumption. In DHF, it should be used in combination with other inotropic agents, for the treatment of cardiogenic shock refractory to other circulatory support measures. Dopamine also has beta and alphaadrenergic effects, the latter at doses higher than $10 \mu \mathrm{g} /$ $\mathrm{kg} / \mathrm{min}$ - the usual dose ranges from 2 to $20 \mu \mathrm{g} / \mathrm{kg} / \mathrm{min}$. It is also associated with increased heart rate, myocardial oxygen consumption, myocardial ischemia, and ventricular $\operatorname{arrhythmias}^{(33)}$.

In DHF, discontinuation of betablockers remains controversial in the daily practice. In most of the patients with DHF (profile B - "wet-warm"), it is not necessary to discontinue or reduce betablockers. Despite the scarce literature available ${ }^{(34,35)}$, it seems clear that the abrupt withdrawal of betablockers may increase sympathetic activation even further (which is invariably already elevated in DHF), thus favoring apoptosis and arrhythmias, with a consequent reduction in survival. When inotropic drugs are necessary in patients with DHF previously using betablockers, the use of drugs that do not act in beta-adrenergic receptors such as milrinone and levosimendan may be considered. In patients with cardiogenic shock chronically using high doses of betablockers, the use of dobutamine is irrefutable, as well as the reduction and/ or discontinuation of betablockers.

\section{Management of hypervolemia}

\section{Diuretics $^{(36)}$}

Diuretics reduce extracellular fluids, filling pressures and cardiac cavities, with a consequent improvement of performance, thus promoting fast symptomatic relief of congestion. They may be associated with adverse effects such as hypotension, abnormal serum electrolyte levels, renal dysfunction and neurohormonal activation by hypovolemia. The use of diuretics must be rational and judicious, aiming to preserve renal function (the lowest possible dose with the best result). The loop diuretics furosemide and bumetanide are the most indicated. In patients resistant to diuretics, continuous intravenous use is possible, as well as the combination with thyazide and aldosterone antagonists. In "new" acute HF diuretics should be carefully used, because some of these patients show normovolemia, or even hypovolemia ${ }^{(37)}$.

\section{Hypertonic saline solution}

A study with patients resistant to oral loop diuretics showed preservation and improvement of the renal function with the use of $150 \mathrm{~mL}$ of $\mathrm{NaCl}$ solution at a concentration of 1.4 to $4.6 \%$ (according to the patient's serum sodium levels) followed by a high dose of intravenous furosemide, in comparison to the group which received intravenous furosemide alone ${ }^{(38)}$. Brazilian studies have also demonstrated preservation of the renal function and increased diuresis ${ }^{(39,40)}$. The profile of patients eligible for this procedure includes those with hyponatremia, systemic congestion (ascites and peripheral edema) and worsening of the renal function with the use of diuretics.

\section{Ultrafiltration}

This procedure is performed via a peripheral intravenous line, and can be potentially used in hypervolemic patients, those with frequent rehospitalizations, and on a day-hospital basis. A study has demonstrated reduction in weight and rehospitalizations within 90 days in comparison to the treatment with diuretics, despite a more pronounced initial elevation of creatinine ${ }^{(41)}$. A more recent trial has not shown any benefit with the use of this strategy ${ }^{(42)}$.

\section{SURGICAL TREATMENT}

In patients with DHF secondary to ACS, coronary angiography is mandatory and may guide revascularization strategies (whether percutaneous or surgical). Likewise, acute valvular heart diseases may require percutaneous or surgical treatment ${ }^{(7)}$.

For patients with DHF, especially those with cardiogenic shock irresponsive to medical treatment with diuretics, vasodilators and inotropic drugs, the use of ventricular assist devices (VAD) may be considered. These may classified as short or long-term devices. Shortterm devices include intra-aortic baloon pump, ECMO, impella $^{\mathrm{TM}}$, transcore $^{\mathrm{TM}}$, rota-flow ${ }^{\mathrm{TM}}$ and centrimag ${ }^{\mathrm{TM}}$; they may be used as bridge to recovery (cardiogenic shock 
in ACS, post-cardiotomy and myocarditis), bridge to decision (post-cardiopulmonary arrest), and bridge to bridge (stabilization and implantation of a long-term VAD). The long-term devices or artificial ventricles (paracorporeal or implantable) are considered as bridge to transplantation or as destination therapy (when transplantation is contraindicated) ${ }^{(43)}$.

Patients with HF refractory to medical treatment and frequent hospitalizations for DHF may be considered eligible for surgical treatment including VAD and cardiac transplantation ${ }^{(44)}$.

\section{CONCLUSION}

DHF is a frequent cause of hospitalization and has a high risk of rehospitalization and mortality. From the diagnosis and risk stratification of DHF, determination of the clinical hemodynamic profile is fundamental to guide therapy including non-pharmacological and pharmacological measures, and, in refractory cases, VAD and cardiac transplantation.

\section{REFERENCES}

1. Bocchi EA, Vilas-Boas F, Perrone S, Caamaño AG, Clausell N, Moreira Mda C, Thierer J, Grancelli HO, Serrano Junior CV, Albuquerque D, Almeida D, Bacal F, Moreira LF, Mendonza A, Magaña A, Tejeda A, Chafes D, Gomez E, Bogantes E, Azeka E, Mesquita ET, Reis FJ, Mora H, Vilacorta H, Sanches J, Souza Neto Dd, Vuksovic JL, Moreno JP, Aspe y Rosas J, Moura LZ, Campos LA, Rohde LE, Javier MP, Garrido Garduño M, Tavares M, Castro Gálvez P, Spinoza R, Castro de Miranda R, Rocha RM, Paganini R, Castano Guerra R, Rassi S, Lagudis S, Bordignon S, Navarette S, Fernandes W, Pereira Barretto AC, Issa V, Guimarães Jl; Grupo de Estudos de Insuficiência Cardíaca; Brazilian Society of Cardiology; Argentine Federation of Cardiology; Argentine Society of Cardiology; Chilean Society of Cardiology; Costa Rican Association of Cardiology; Colombian Society of Cardiology; Equatorian Society of Cardiology; Guatemalan Association of Cardiology; Peruvian Society of Cardiology; Uruguayan Society of Cardiology; Venezuelan Society of Cardiology; Mexican Society of Cardiology; Mexican Society of Heart Failure; Interamerican Society of Heart Failure. I Latin American Guidelines for the Assessment and Management of Decompensated Heart Failure. Arq Bras Cardiol. 2005;85 Suppl 3:49-94; 1-48.

2. Hunt SA, Abraham WT, Chin MH, Feldman AM, Francis GS, Ganiats TG, et al. 2009 focused update incorporated into the ACC/AHA 2005 Guidelines for the Diagnosis and Management of Heart Failure in Adults: a report of the American College of Cardiology Foundation/American Heart Association Task Force on Practice Guidelines: developed in collaboration with the International Society for Heart and Lung Transplantation. Circulation. 2009;119(14): e391-479.

3. McMurray JJ, Adamopoulos S, Anker SD, Auricchio A, Böhm M, Dickstein K, Falk V, Filippatos G, Fonseca C, Gomez-Sanchez MA, Jaarsma T, Køber L, Lip GY, Maggioni AP, Parkhomenko A, Pieske BM, Popescu BA, Rønnevik PK, Rutten FH, Schwitter J, Seferovic P, Stepinska J, Trindade PT, Voors AA, Zannad F, Zeiher A; Task Force for the Diagnosis and Treatment of Acute and Chronic Heart Failure 2012 of the European Society of Cardiology, Bax JJ, Baumgartner H, Ceconi C, Dean V, Deaton C, Fagard R, Funck-Brentano C, Hasdai D, Hoes A, Kirchhof P, Knuuti J, Kolh P, McDonagh T, Moulin C, Popescu BA, Reiner Z, Sechtem U, Sirnes PA, Tendera M, Torbicki A, Vahanian A, Windecker S, McDonagh T, Sechtem U, Bonet LA, Avraamides P, Ben Lamin HA, Brignole M, Coca A, Cowburn P, Dargie H, Elliott P, Flachskampf
FA, Guida GF, Hardman S, lung B, Merkely B, Mueller C, Nanas JN, Nielsen OW, Orn S, Parissis JT, Ponikowski P; ESC Committee for Practice Guidelines. ESC guidelines for the diagnosis and treatment of acute and chronic heart failure 2012: The Task Force for the Diagnosis and Treatment of Acute and Chronic Heart Failure 2012 of the European Society of Cardiology. Developed in collaboration with the Heart Failure Association (HFA) of the ESC. Eur J Heart Fail. 2012;14(8):803-69. Erratum in: Eur J Heart Fail. 2013;15(3):361-2.

4. Brasil. Ministério da Saúde. Datasus: morbidade hospitalar do SUS por local de internação - Brasil [Internet]. Brasília (DF):Ministério da Saúde; c2008. [citado 2013 Set 18]. Disponível em: http://tabnet.datasus.gov.br/cgi/tabcgi. exe?sih/cnv/niuf.def

5. Gheorghiade M, Zannad F, Sopko G, Klein L, Piña IL, Konstam MA, Massie BM, Roland E, Targum S, Collins SP, Filippatos G, Tavazzi L; International Working Group on Acute Heart Failure Syndromes. International working group on acute heart failure syndromes. Acute heart failure syndromes: current state and framework for future research. Circulation. 2005;112(25):3958-68.

6. Adams KF Jr, Fonarow GC, Emerman CL, LeJemtel TH, Costanzo MR, Abraham WT, Berkowitz RL, Galvao M, Horton DP; ADHERE Scientific Advisory Committee and Investigators. Characteristics and outcomes of patients hospitalized for heart failure in the United States: rationale, design and preliminary observations from the first 100000 cases in the Acute Decompensated Heart Failure National Registry (ADHERE). Am Heart J 2005; 149(2):209-16

7. Mangini S, Silveira FS, Silva CP, Grativvol PS, Seguro LF, Ayub SM, et al. Insuficiência cardíaca descompensada na unidade de emergência de hospital especializado em cardiologia. Arq Bras Cardiol 2008;90(6):400-6.

8. Montera MW, Pereira SB, Colafranceschi AS, Almeida DR, Tinoco EM, Rocha RM et al. Summary of the II Brazilian Guideline update on Acute Heart Failure 2009/2011. Arq Bras Cardiol. 2012;98(5):375-83.

9. Wang CS, FitzGerald JM, Schulzer M, Mak E, Ayas NT. Does this dyspneic patient in the emergency department have congestive heart failure? JAMA 2005;294(15):1944-56.

10. Nohria A, Tsang AW, Fang JC, Lewis EF, Jarcho JA, Mudge GH, et al. Clinical assessment identifies hemodynamic profiles that predict outcomes in patients admitted with heart failure. J Am Coll Cardiol. 2003;41(10):1797-804.

11. Maisel AS, Krishnaswamy $P$, Nowak RM, McCord J, Hollander JE, Duc $P$ Omland T, Storrow AB, Abraham WT, Wu AH, Clopton P, Steg PG, Westheim A, Knudsen CW, Perez A, Kazanegra R, Herrmann HC, McCullough PA; Breathing Not Properly Multinational Study Investigators. Rapid measurement of B-type natriuretic peptide in the emergency diagnosis of heart failure. N Engl $\mathrm{J}$ Med. 2002;347(3):161-7.

12. Januzzi JL Jr, Camargo CA, Anwaruddin S, Baggish AL, Chen AA, Krauser $D G$, et al. The N-terminal Pro-BNP investigation of dyspnea in the emergency department (PRIDE) study. Am J Cardiol. 2005;95(8):948-54.

13. Jourdain $P$, Jondeau G, Funck F, Gueffet P, Le Helloco A, Donal E, et al. Plasma brain natriuretic peptide-guided therapy to improve outcome in heart failure. The STARS-BNP multicenter study. J Am Coll Cardiol. 2007;49(16):1733-39.

14. Pfisterer M, Buser P, Rickli H, Gutmann M, Erne P, Rickenbacher P, Vuillomenet A, Jeker U, Dubach P, Beer H, Yoon SI, Suter T, Osterhues HH, Schieber MM, Hilti P, Schindler R, Brunner-La Rocca HP; TIME-CHF Investigators. BNPguided vs symptom-guided heart failure therapy: the Trial of Intensified vs Standard Medical Therapy in Elderly Patients With Congestive Heart Failure (TIME-CHF) randomized trial. JAMA. 2009;301(4):383-92.

15. Marcondes-Braga FG, Gutz IG, Batista GL, Saldiva PH, Ayub-Ferreira SM, Issa VS, et al. Exhaled acetone as a new biomaker of heart failure severity. Chest. 2012;142(2):457-66.

16. Cotter G, Cotter OM, Kaluski E. Hemodynamic monitoring in acute heart failure. Crit Care Med. 2008;36:S40-3.

17. Binanay C, Califf RM, Hasselblad V, O'Connor CM, Shah MR, Sopko G, Stevenson LW, Francis GS, Leier CV, Miller LW; ESCAPE Investigators and ESCAPE Study Coordinators. Evaluation study of congestive heart failure and pulmonary artery catheterization effectiveness (The ESCAPE Trial). JAMA. 2005;294(13):1625-33. 
18. Fonarow GC, Adams KF Jr, Abraham WT, Yancy CW, Boscardin WJ: ADHERE Scientific Advisory Committee, Study Group, and Investigators. Risk stratification for in-hospital mortality in acutely decompensated heart failure: classification and regression tree analysis. JAMA. 2005;293(5):572-80.

19. Metra M, Cotter G, Gheorghiade M, Dei Cas L, Voors AA. The role of the kidney in heart failure. Eur Heart J. 2012;33(17):2135-42.

20. Smith GL, Vaccarino V, Kosiborod M, Lichtman JH, Cheng S, Watnick SG, et al. Worsening renal function: what is a clinically meaningful change in creatinine during hospitalization with heart failure? J Card Fail. 2003;9(1):13-25.

21. de Luca L, Fonarow GC, Adams Jr KF, Mebazaa A, Tavazzi L, Swedberg K, et al. Acute Heart failure syndromes: clinical scenarios and pathophysiologic targets for therapy. Heart Fail Rev. 2007;12(2):97-104.

22. Peter JV, Moran JL, Phillips-Hughes J, Graham P, Bersten AD. Effect of noninvasive positive pressure ventilation on mortality in patients with acute cardiogenic pulmonary oedema: a meta-analysis. Lancet. 2006;367(9517): 1155-63.

23. Abraham WT, Adams KF, Fonarow GC, Costanzo MR, Berkowitz RL, LeJemtel TH, ChengmL, Wynne J; ADHERE Scientific Advisory Committee and Investigators; ADHERE Study Group. In-hospital mortality in patients with acute decompensated heart failure requiring intravenous vasoactive medications (ADHERE). J Am Coll Cardiol. 2005;46(1):57-64.

24. Mullens W, Abrahams Z, Francis GS, Skouri HN, Starling RC, Young JB, et al. Sodium nitroprusside for advanced low-output heart failure. J Am Coll Cardiol. 2008;52(3):200-7.

25. Elkayam U, Janmohamed M, Habib M, Hatamizadeh P. Vasodilators in the management of acute heart failure. Crit Care Med. 2008;36(1 Suppl):S95-105.

26. Petersen JW, Felker M. Inotropes in the management of acute heart failure. Crit Care Med. 2008;36(1 Suppl):S106-11.

27. O'Connor CM, Gattis WA, Uretsky BF, Adams KF Jr, McNulty SE, Grossman $\mathrm{SH}$, et al. Continuous intravenous dobutamine is associated with an increased risk of death in patients with advanced heart failure: insights from the Flolan International Randomized Survival Trial (FIRST). Am Heart J. 1999;138(1 Pt 1):78-86.

28. Cuffe MS, Califf RM, Adams KF Jr, Benza R, Bourge R, Colucci WS, Massie BM, O'Connor CM, Pina I, Quigg R, Silver MA, Gheorghiade M; Outcomes of a Prospective Trial of Intravenous Milrinone for Exacerbations of Chronic Heart Failure (OPTIME-CHF) Investigators. Outcomes of a Prospective Trial of Intravenous Milrinone for Exacerbations of Chronic Heart Failure (OPTIME-CHF) investigators. Short-term intravenous milrinone for acute exacerbation of chronic heart failure: a randomized controlled trial. JAMA. 2002;287(12):1541-7.

29. Nieminem MS, Akkila J, Hasenfuss G, Kleber FX, Lehtonen LA, Mitrovic V, et al. Hemodynamic and neurohormonal effects of continuous infusion of levosimendan in patients with congestive heart failure. J Am Coll Cardiol. 2000;36(6):1903-12

30. Follath F, Cleland JG, Just H, Papp JG, Scholz H, Peuhkurinen K, Harjola VP, Mitrovic V, Abdalla M, Sandell EP, Lehtonen L; Steering Committee and Investigators of the Levosimendan Infusion versus Dobutamine (LIDO) Study. Efficacy and safety of intravenous levosimendan compared with dobutamine in severe low-output heart failure (the LIDO study): a randomized double-blind trial. Lancet. 2002;360(9328):196-202.

31. Moiseyev VS, Põder P, Andrejevs N, Ruda MY, Golikov AP, Lazebnik LB, Kobalava ZD, Lehtonen LA, Laine T, Nieminen MS, Lie KI; RUSSLAN Study Investigators. Randomized study on safety and effectiveness of levosimendan in patients with left ventricular failure after an acute myocardial infarction (RUSSLAN). Eur Heart J. 2002;23(18):1422-32.

32. Mebazaa A, Nieminen MS, Packer M, Cohen-Solal A, Kleber FX, Pocock SJ, Thakkar R, Padley RJ, Põder P, Kivikko M; SURVIVE Investigators. Levosimendan vs dobutamine for patients with acute decompensated Herat failure. The SURVIVE randomized trial. JAMA. 2007;297(17):1883-91.

33. Van De Borne P, Somers VK. Dopamine and congestive heart failure: pharmacology, clinical use and precautions. Congest Heart Fail. 1999;5(5):216-21.

34. Gattis WA, O'Connor CM, Leimberger JD, Felker GM, Adams KF, Gheorghiade M. Clinical outcomes in patients on betablocker therapy admitted with worsening chronic heart failure. Am J Cardiol. 2003;91 (2):169-74.

35. Metra M, Torp-Pedersen C, Cleland JG, Di Lenarda A, Komajda M, Remme WJ, Dei Cas L, Spark P, Swedberg K, Poole-Wilson PA; COMET investigators. Should betablocker therapy be reduced or withdrawn after episode of decompensaded heart failure? Eur J Heart Failure. 2007;9(9):901-99.

36. Wang DJ, Gottlieb SS. Diuretics: still the mainstay of treatment. Crit Care Med. 2008;36(1 Suppl):S89-94.

37. Chatti R, Fradj NB, Trabelsi W, Kechiche H, Tavares M, Mebazaa A. Algorithm for therapeutic management of acute heart failure syndromes. Heart Fail Rev. 2007;12(2):113-7.

38. Paterna S, Di Pasquale P, Parrinello G, Fornaciari E, Di Gaudio F, Fasullo S, et al. Changes in brain natriuretic peptide levels and bioelectrical impedance measurements after treatment with high-dose furosemide and hypertonic saline solution versus high-dose furosemide alone in refractory congestive heart failure. J Am Coll Cardiol. 2005;45(12):1997-2003.

39. Issa VS, Bacal F, Mangini S, Carneiro RM, Azevedo CH, Chizzola PR, et al. Solução salina hipertônica para prevenção de insuficiência renal em pacientes com insuficiência cardíaca descompensada e hiponatremia. Arq Bras Cardiol. 2007:89:251-5.

40. Issa VS, Andrade L, Ayub-Ferreira SM, Bacal F, de Bragança AC, Guimarães GV, et al. Hypertonic saline solution for prevention of renal dysfunction in patients with decompensated heart failure. Int J Cardiol. 2013;167(1):34-40

41. Costanzo MR, Guglin ME, Saltzberg MT, JessupmL, Bart BA, Teerlink JR, Jaski BE, Fang JC, Feller ED, Haas GJ, Anderson AS, Schollmeyer MP, Sobotka PA; UNLOAD Trial Investigators. Ultrafiltration versus intravenous diuretics for patients hospitalized for acute decompensated heart failure. UNLOAD. J Am Coll Cardiol. 2007;49(6):675-83. Erratum in: J Am Coll Cardiol. 2007;49(10):1136.

42. Bart BA, Goldsmith SR, Lee KL, Givertz MM, O'Connor CM, Bull DA, Redfield MM, Deswal A, Rouleau JL, LeWinter MM, Ofili EO, Stevenson LW, Semigran MJ, Felker GM, Chen HH, Hernandez AF, Anstrom KJ, McNulty SE, Velazquez EJ, Ibarra JC, Mascette AM, Braunwald E; Heart Failure Clinical Research Network. Ultrafiltration in decompensated heart failure with cardiorenal syndrome. N Engl J Med. 2012;367(24):2296-304.

43. Miller LW, Guglin M. Patient selection for ventricular assist devices: a moving target. J Am Coll Cardiol. 2012;61(12):1209-21

44. Bacal F, Neto JD, Fiorelli Al, Mejia J, Marcondes-Braga FG, Mangini S, Oliveira Jde L Jr, de Almeida DR, Azeka E, Dinkhuysen JJ, Moreira Mda C, Neto $J M$, Bestetti RB, Fernandes JR, Cruz Fd, Ferreira LP, da Costa HM, Pereira AA, Panajotopoulos N, Benvenuti LA, Moura LZ, Vasconcelos GG, Branco JN, Gelape CL, Uchoa RB, Ayub-Ferreira SM, Camargo LF, Colafranceschi AS, Bordignon S, Cipullo R, Horowitz ES, Branco KC, Jatene M, Veiga SL, Marcelino CA, Teixeira Filho GF, Vila JH, Montera MW; Sociedade Brasileira de Cardiologia. II Brazilian Guidelines for Cardiac Transplantation. Arq Bras Cardiol. 2010;94(1 Suppl):e16-76. Article in Portuguese. 